\title{
PENDIDIKAN TOLERANSI DAN RELEVANSINYA DENGAN DINAMIKA SOSIAL MASYARAKAT INDONESIA
}

\author{
FAJRI SODIK
}

\begin{abstract}
The State of Indonesia is known for its pluralistic ethnic society that is constantly undergoing changes in every aspect of life. Tolerance education embedded in society aims to make citizens aware of equality in the life of the nation and state so they are be able to form harmonious Indonesian society side by side. This paper aims to describe the importance of tolerance education in the social dynamics of Indonesian people living in diversity. The method used in this research is literature study (literature review). The results of this study indicate that tolerance education is very relevant in the social dynamics of Indonesian society. The tolerance values that must be instilled by the Indonesian people in daily life include: mutual respect, brothers and sisters, freedom, cooperation, mutual help, non-discrimination and a culture of sharing. With the existence of tolerance education, the Indonesian people can live in harmony and spared from conflict and animosity between fellow citizens.
\end{abstract}

Keywords: Tolerance, social dynamics, society

\section{Pendahuluan}

Indonesia adalah negara yang dikenal dengan masyarakat etnik pluralistik yang senantiasa mengalami perubahan dalam setiap aspek kehidupan, baik dalam segi kemasyarakatan maupun dalam segi kebudayaan. Oleh karena itu, dinamika sosial masyarakat Indonesia akan terus berjalan dengan cepat ataupun lambat seiring dengan perubahan zaman (Marnelly, 150, 2017). Pluralitas dalam masyarakat Indonesia menjadi perpaduan yang indah dalam berbagai hal yang penuh dengan keberagaman. Artinya setiap suku, agama, ras, adat-istiadat, kebudayaan maupun golongan mampu hidup secara berdampingan dan mampu menerima keberagaman dalam setiap aspek kehidupan yang istilahnya kita kenal dengan nama toleransi.

Menurut Kuntowijoyo dalam (Digdoyo, 2018: 43), dunia menjadi saksi akan keindahan dan keberagaman masyarakat Indonesia yang berada di tengah-tengah khatulistiwa. Namun, dunia pun menjadi saksi karena sempitnya pemikiran masyarakat Indonesia dalam suku, agama, ras, adatistiadat, kebudayaan maupun golongan tertentu yang terpecah belah dengan adanya konflik. Konflik-konflik yang berakar dari perbedaan agama, etnis, bahasa, ekonomi, dan politik tidak bisa dihindari (Rasimin, 2016: 100). Sehingga, pada satu sisi, keberagaman tersebut akan menjadi indah dan berwarna dalam dinamika sosial masyarakat Indonesia apabila seluruh warga 
masyarakat mampu bersatu dan saling bekerjasama dalam memajukan bangsa. Akan tetapi, di sisi lain, jika tidak dibarengi dengan pendidikan toleransi maka keragaman suku, agama, etnik, dan budaya tersebut akan mengakibatkan konflik bahkan perpecahan antar masyarakat Indonesia.

Kalimat "Bhinneka Tunggal Ika" yang berarti berbeda-beda tetapi tetap satu jua bukan hanya semboyan bangsa Indonesia, terlebih lagi sejak Indonesia lepas dari penjajahan kalimat tersebut dijadikan sebagai pemersatu bangsa. Akan tetapi, disebabkan dinamika sosial masyarakat Indonesia yang terus berkembang, semboyan pun tidak menjamin adanya kerukunan dalam masyarakat Indonesia jika tidak dilandasi dengan hati nurani masyarakat itu sendiri. Kenyataannya, ada banyak konflik yang terjadi antar wilayah, suku, agama, ras, adat-istiadat, kebudayaan maupun golongan (Tajuddin dkk, 2016: 64). Seperti halnya konflik yang terjadi akibat tindakan rasisme baru-baru ini yang terjadi di Wamena (2019). Konflik tersebut merupakan konflik yang sangat merugikan masyarakat Indonesia, bukan hanya dari sisi materi dan jiwa saja, tetapi juga menghancurkan sendi-sendi kemanusiaan dan keharmonisan antar sesama masyarakat Indonesia. Itulah yang mengakibatkan pudarnya rasa kebersamaan dan toleransi antara sesama manusia dan menjadikan masyarakat Indonesia rawan konflik yang akhirnya menjadi bangsa yang anti-toleransi. Perasaan benci dan curiga menjadi tanda dari sikap anti-toleransi antar sesama masyarakat Indonesia.

Randa (2017: 7) mengatakan bahwa toleransi adalah sikap saling menghormati, menghargai, dan menerima perbedaan. Fungsi dari toleransi adalah untuk memahami perbedaan, dan pendidikan adalah hal utama yang dapat membentuk sikap toleransi. Melalui pendidikan, pendidikan toleransi akan sangat bermanfaat bagi masyarakat dalam menjalani kehidupan, karena manusia tidak bisa hidup berdiri sendiri melainkan merupakan mahluk sosial. Harus dapat dipahami bahwa setiap manusia mempunyai latar belakang dan cara berfikir yang berbeda beda, dan perbedaan itu tidak seharusnya menjadi masalah yang menyebabkan berbagai perpecahan. Oleh karena itu, dibutuhkan penerapan sikap saling toleransi antar sesama manusia agar kehidupan dapat berjalan dengan indah tanpa konflik ataupun perpecahan. Memiliki toleransi bisa memberikan beragam manfaat untuk kehidupan, diantaranya mampu menciptakan kerukunan dan keharmonisan, memperkuat hubungan antar individu, meningkatkan rasa kebersamaan dan solidaritas serta mampu menciptakan lingkungan masyarakat yang nyaman dan tentram.

Berdasarkan hal tersebut, penelitian ini menemui relevansi dan signifikansinya, karena diharapkan penelitian ini akan mampu memberikan kontribusinya dalam dinamika sosial masyarakat Indonesia yang bisa membawa masyarakat rukun dan harmonis dalam berbangsa dan bernegara di masa sekarang dan di masa yang akan datang. Khususnya bagi masyarakat Indonesia yang dikenal memiliki karakter kuat dalam memegang teguh keagamaan, kebudayaan dan adat-istiadatnya. Sehingga hasil implementasi 
pendidikan toleransi bukan hanya sekedar menghargai dan menghormati keberagaman perbedaan kepercayaan, kebudayaan, adat-istiadat, bahasa dan sebagainya, tapi harus disertai dengan sikap mau menerima demi menciptakan rasa nyaman bagi masyarakat lain dalam mengekspresikan keragaman sikap, adat-istiadat, budaya, dan terutama keyakinan agama tanpa ada perasaan lebih baik dari masyarakat yang lain. Hamidah (2015: 12) mengatakan bahwa rasa toleransi ini jangan hanya dipelajari secara teori saja, namun harus dapat diwujudkan dalam kehidupan bermasyarakat dimanapun berada, baik di lingkungan keluarga, lingkungan sekolah, lingkungan masyarakat, bahkan berbangsa dan bernegara, diantaranya yaitu toleransi agama, toleransi sosial, dan toleransi kultural.

Artikel ini juga ditulis dengan tujuan agar kehidupan masyarakat Indonesia dapat terjalin harmonis dengan mengimplementasikan pendidikan toleransi. Dimensi masyarakat Indonesia yang plural akan terjalin harmonis apabila setiap individu memiliki sikap toleransi satu sama lain. Sejak Indonesia merdeka, ada begitu banyak pertumpahan darah atas dasar perbedaan baik itu karena perbedaan agama, etnis, adat-istiadat maupun golongan yang terjadi akibat tidak adanya kesaling-pahaman antara satu sama lain, yang semestinya terwujud dalam sikap toleransi. Sehingga pentingnya mengimplementasikan pendidikan toleransi dalam dinamika sosial masyarakat Indonesia dalam menjaga keutuhan negara kita NKRI dalam berbangsa dan bernegara.

\section{Metode Penelitian}

Metode penelitian yang digunakan dalam penelitian ini adalah metode deskriptif-analitik dengan pendekatan kualitatif. Adapun teknik pengumpulan data yang digunakan adalah studi literatur, yang dilakukan dengan cara mengumpulkan data dari artikel-artikel ilmiah dan buku-buku yang relevan dengan masalah penelitian.

\section{Pembahasan}

Pendidikan Toleransi

Toleransi dalam bahasa Latin, yaitu "tolerantia", yang artinya kelonggaran, kelembutan hati, keringanan dan kesabaran. Dalam bahasa Arab istilah toleransi dikaitkan dengan "tasamuh" yang artinya berlaku baik, lemah lembut dan saling pemaaf. Secara umum istilah toleransi mengacu pada sikap saling terbuka, permisif, tulus dan lembut. Menurut Mawarti (2017: 70), yang dimaksud dengan toleransi adalah yang berkaitan dengan hubungan atar sesama manusia yang saling menghargai dan penuh dengan kerja sama. Toleransi artinya menghargai, membolehkan pendapat, kepercayaan, dan sebagainya dari individu lain yang bertolak belakang degan pemikirannya sendiri (Hamidah, 2015:11). 
Berdasarkan pengertian-pengertian di atas, dapat dipahami bahwa toleransi adalah suatu sikap saling menghormati dan menerima dengan rendah hati terhadap perbedaan-perbedaan yang terjadi. Manusia yang memiliki sikap toleransi ialah manusia yang sabar, lapang dada, menghargai, dan menerima, karena tanpa sikap tersebut akan sulit bahwa toleransi akan tertanam dalam kehidupan masyarakat yang beragam.

Sikap toleransi dalam kehidupan masyarakat tidak bisa timbul dari sebelah pihak namun harus melibatkan seluruh anggota masyarakat baik dalam sekelompok masyarakat kecil maupun masyarakat yang besar. Kebanyakan masyarakat berpikiran bahwa toleransi itu cukup dilaksanakan oleh sekelompok masyarakat besar saja, padahal jika ingin kehidupan yang nyaman dan tentram kaum minoritaspun harus melaksanakan sikap toleransi. Ada dua penafsiran dalam memaknai konsep toleransi. Pertama, penafsiran negatif yang mengatakan bahwa toleransi cukup dilaksanakan dengan tidak menyakiti masyarakat lain. Sedangkan penafsiran yang kedua adalah penafsiran positif dimana toleransi bukan hanya tidak menyakiti orang lain melainkan harus dibarengi dengan bantuan dan dukungan terhadap masyarakat lain (Hamidah, 2015: 12)

Bagi bangsa Indonesia, pendidikan toleransi yaitu pendidikan yang bukan hanya masalah teori dan pengetahuan saja, terlebih lagi dapat menghasilkan masyarakat yang mempunyai local wisdom (kearifan lokal) atau masyarakat yang berpandangan inklusif (memposisikan pribadi sendiri ke dalam posisi yang sama dengan yang lain). Keragaman tersebut merupakan kekuatan yang dapat memperindah masyarakat apabila satu sama lain saling memperkuat dan saling bekerja sama dalam membangun bangsa. Namun, di sisi lain, keragaman tersebut jika tidak di kelola dengan tepat akan menyebabkan perselisihan atau konflik yang meruntuhkan bangsa. Oleh karena itu, sikap toleransi antar sesama manusia dalam dinamika sosial adalah sebuah modal dasar (Rosyid, 2016:76).

Ada beberapa pendekatan yang dapat dilakukan dalam pendidikan toleransi, yaitu pendekatan perorangan, pendekatan kelompok dan pendekatan klasikal. Pendidikan formal dan non-formal yang keduanya bertujuan untuk mempertahankan nilai-nilai dan budaya bangsa dari derasnya arus globalisasi dan modernisasi. Lima dimensi dalam pendidikan harus tetap terjaga yaitu, 1) intelektual; 2) kultural; 3) nilai-nilai transendental; 4) keterampilan fisik/jasmani; 5) pembinaan kepribadian manusia sendiri (Hamidah, 2015:16). Dengan beberapa dimensi dan pendekatan tersebut, pedidikan toleransi diharapkan mampu ditanamkan dan diamalkan dengan baik oleh warga masyarakat.

Secara kodrati, manusia adalah mahluk yang diciptakan untuk hidup dalam keharmonisan. Perbedaan fisik, jasmani ataupun gender sebenarya adalah kehendak sang maha pencipta yang seyogianya bisa dijadikan dasar dalam menciptakan kehidupan yang penuh dengan sikap toleransi. Perbedaan 
yang ada dalam kebudayaan suku bangsa dan agama bersama dengan kehidupan berbangsa dan bernegara dalam kehidupan sehari-hari (Ghazali \& Busro, 2017: 109). Dari pemaparan-pemaparan diatas, dapat ditarik sebuah kesimpulan bahwa pendidikan toleransi adalah salah satu upaya untuk menanamkan sikap saling menghormati, memahami dan menghargai dalam setiap perbedaan baik dalam keyakinan, suku, ras, maupun budaya.

\section{Dinamika sosial}

Dalam kaidah sosiologi, pengertian dinamika sosial yaitu sebagai perubahan seluruh warga masyarakat dalam segala aspek yang terus berkembang dari waktu ke waktu. Hamidah (2015: 11) mengatakan bahwa dinamika sosial berarti bahwa setiap masyarakat terus mengalami perubahan dan perkembangan. Perubahan tersebut akan selalu terjadi dalam setia kelompok sosial. Namun, perubahan-perubahan itu bisa bergerak dengan lambat (retrogresif), bisa juga bergerak dengan cepat (progresif) (Lumintang, 2015).

Dinamika sosial di dalam kelompok masyarakat pada umumnya mengalami perubahan sebagai akibat dari derasnya arus modernisasi dan globalisasi, sebagai contohnya yaitu dari adanya perselisihan dalam kelompok tersebut (Marnelly, 2017: 149). Ada individu yang dengan maskud merebut kekuasaan dengan mengorbankan individu lainnya, serta ada maksud dan tujuan yang tidak seimbang yang mengakibatkan perbedaan dan ketidakadilan tentang cara memenuhi maksud dan tujuan tertentu. Maksud dan tujuan tersebut meyebabkan permasalahan bahkan perpecahan di dalam kelompok masyarakat, yang pada akhirnya terjadilah perubahan atau dinamika sosial (Soekamto, 2006, 147).

Merutut Baharrudin (2015: 184) ada beberapa bentuk dinamika sosial, yang pertama perubahan evolusi dan revolusi. Perubahan evolusi yaitu perubahan sosial yang terjadi dengan sangat lambat karena perubahan bentuk ini merupakan perubahan yang diakibatkan adanya dorongan dari suatu kelompok masyarakat dalam memenuhi kebutuhan hidup. Seperti halnya adanya perubahan dalam sistem komunikasi dari waktu ke waktu. Sebaliknya, perubahan revolusi terjadi dalam waktu yang sangat cepat dan membawa perubahan-perubahan besar yang bisa disebakan karena adanya konflik dalam masyarakat. Kedua, perubahan yang dikehendaki dan tidak dikehendaki. Perubahan yang dikehendaki dengan kata lain adalah perubahan yang direncanakan, misalnya perubahan yang dilakukan oleh pemerintah. Semetara perubahan yang tidak dikehendaki atau yang tidak direncanakan, misalnya pengaruh dari budaya masyarakat yang tidak bisa dihindari. Ketiga yaitu perubahan kecil dan besar. Perubahan kecil yaitu perubahan yang tidak terlalu berpegaruh pada masyarakat seperti pgaya berpakaian atau model rambut. Sedangkan perubahan besar yaitu perubahan yang berpengaruh pada 
masyarakat, seperti penggunaan alat traktor sangat membawa pengaruh besar dalam industri pertanian. (Baharrudin, 2015: 184-185).

Berdasarkan uraian diatas, masyarakat yang plural seperti masyarakat Indonesia tidak akan terlepas dari istilah dinamika sosial. Dinamika atau perubahan sosial yang bisa terjadi karena adanya evolusi dan revolusi, perubahan yang direncanakan dan tidak direncanakan, serta perubahan kecil dan besar pasti akan dilalui oleh masyarakat Indonesia. Dinamika sosial tersebut akan membawa dampak positif ataupun negatif akan tergantung dengan masyarakatnya sendiri.

\section{Masyarakat Indonesia}

Masyarakat dalam bahasa latin yaitu "socius" yang berarti "kawan". Dalam bahasa Inggris dipakai istilah society. Para ilmuan menyepakati bahwa tidak ada definisi khusus dalam mengartikan masyarakat, karena dari waktu ke waktu sifat manusia itu secara alamiah akan selalu berubah. Hal tersebut menyebabkan terdapat berbagai macam definisi masyarakat, menurut Selo Soemardjan dalam (Baharuddin, 2015: 182) mengatakan bahwa masyarakat bisa dikatakan sebagai mahluk yang hidup dan menciptakan kebudayaan. Sedangkan menurut Max Weber, masyarakat adalah sebuah struktur yang ditentukan oleh nilai-nilai utama dalam warganya yang selalu membutuhkan interaksi dengan individu lainnya dalam sekelompok masyarakat.

Berdasarkan pengertian-pengertian di atas, dapat dikatakan bahwa masyarakat adalah sekumpulan kelompok yang mempunyai ikatan dan kesamaan dalam beberapa hal seperti dalam budaya, sikap, dan perilaku yang membentuk satu kesatuan yang dinamis. Kehidupan dinamis masyarakat tidak bisa dihindari, karena manusia adalah mahluk yang saling membutuhkan dan tidak bisa hidup mandiri di dalam lingkungannya. Setiap anggota masyarakat memiliki perannya masing-masing dan saling berhubungan satu sama lain (Muawanah, 2018: 63).

Adapun dua macam masyarakat menurut (Tejokusumo, 2014: 41-42), yang pertama yaitu masyarakat modern. Masyarakat ini tidak menjadikan adat-istiadat sebagai dasar dalam kehidupannya, masyarakat modern selalu menganggap bahwa adat-istiadat yang menghambat kemajuan harus diganti dengan menerapkan nila-nilai yang mudah diterima secara rasional. Sedangkan yang kedua adalah masyarakat tradisional yang masih memegang teguh tradisi dan menjadikan adat-istiadat sebagai patokan dalam menjalankan kehidupan sehari-hari sehingga mudah menaruh rasa curiga terhadap perubahan ataupun hal-hal baru. Sehingga dapat disimpulkan bahwa perbedaan-perbedaan yang sekelompok masyarakat akan selalu ada, terlebih masyarakat Indonesia yang terdiri dari berbagai suku, ras, agama dan golongan.

Penjelasan di atas memperkuat hipotesis bahwa dinamika kehidupan sosial masyarakat adalah salah satu hal yang bisa menjadi sumber 
pembelajaran bagi manusia seperti mengajarkan kepada masyarakat agar menyadari hak dan kewajiban terhadap dirinya sendiri maupun terhadap individu lain, masyarakat, bangsa bahkan negara dengan mengimplementasikan pendidikan toleransi.

\section{Pendidikan Toleransi dan Relevansinya dengan Dinamika Sosial Masyarakat Indonesia}

Dinamika sosial yang semakin berubah seiring dengan perkembangan zaman mengakibatkan melemahnya sikap toleransi dalam kehidupan masyarakat Indonesia. Hal ini bisa ditandai dengan maraknya persaingan antar kelompok masyarakat yang bukan hanya diakibatkan karena perbedaan kepercayaan atau perebutan wilayah saja, tapi juga bisa terjadi karena rasa toleransi yang mulai pudar dan tidak lagi tertanam dalam jiwa masyarakat. Apalagi sekarang ini, ideologi bermunculan yang membuat masyarakat Indonesia bersikap intoleran (Qadir, 2016: 431).

Sikap intoleran menyebabkan hancur dan rusaknya persatuan dan kesatuan bangsa Indonesia. Salah satu contoh baru-baru ini yaitu bentrokan antara warga Surabaya dengan mahasiswa Papua yang dipicu oleh tindakan rasisme. Jika masyarakat Indonesia mengimplementasikan pendidikan toleransi, tidak akan ada warga masyarakat yang akan saling merendahkan satu sama lain sehingga bentrokan-bentrokan tersebut tidak akan pernah terjadi. Dengan kurangnya pendidikan toleransi, keberagaman yang seharusnya menjadi keharmonisan dan keindahan malah berujung menjadi perpecahan (Muawanah, 2018: 57).

Terkikisnya sikap toleransi masyarakat Indonesia juga karena mudahnya teprovokasi berita-berita hoax di kalangan masyarakat terutama yang tersebar luas melalui media sosial. Sisi lain dari media sosial yang dimanfaatkan oleh segelintir orang untuk memecah belah persatuan dan kesatuan negara Indonesia dengan menyebarkan propaganda dan hoax serta hal negatif lainnya (Santosa, 2017: 208). Toleransi dalam kehidupan seharihari sangat bermanfaat dalam menjaga keutuhan dan ketentraman di masyarakat Indonesia.

Perdamaian akan selalu menjadi tujuan utama bagi bangsa yang selalu mengutamakan sikap toleransi. Nilai-nilai toleransi yang dijunjung tinggi dan dibarengi dengan ajaran norma yang baik yang memahami keragaman dan mementingkan persatuan dan kesatuan akan melahirkan perdamaian dunia dan ketentraman bangsa. Dengan mengabaikan keragaman serta mengutamakan rasa saling memahami dan menghormati sebagai masyarakat dan tidak merasa bahwa diri tidak sempurna maka akan menjadikannya sebuah senjata yang dapat menghindarkan warag masyarakat dari pertikaian maupun konflik.

Rasa toleransi yang ada dalam keragaman dalam bersosialisasi atau bermusyawarah akan meningkatkan keamanan, ketentraman dalam 
kehidupan bermasyarakat Indonesia sehingga setiap warga mampu mengembangkan kekayaan alam dan sumber daya manusianya (SDM) dengan nyaman dan bersemangat. Kondisi tersebut dapat mempermudah kemajuan bangsa dalam berbagai aspek kehidupan masyarakat Indonesia. Segala bentuk toleransi yang membiarkan orang lain mengemukakan pendapatnya tanpa diintimidasi baik itu dalam beragama maupun dalam bermusyawarah akan meningkatkan rasa tenang dalam kehidupan berbangsa dan bernegara (Muawanah, 2018: 65).

Sabda Rasulullah SAW dalam hadist riwayat Muslim yang artinya "Jadilah kamu hamba Allah yang bersaudara." (HR. Muslim), hadits tersebut menyerukan tentang pentingnya tasamuh yaitu hidup yang saling berdampingan secara rukun seperti saudara. Masyarakat yang berjiwa tasamuh atau toleransi akan senantiasa memancarkan pesona yang meneduhkan terhindar dari pandangan-pandangan negatif masyarakat lain. Dengan bersikap tasamuh maka dalam kehidupan bermasyarakat akan memiliki banyak teman dan saudara. Bahkan di dalam UUD ‘ 45 pada Pasal 28J ditegaskan kembali tentang keharusan setiap warga masyarakat dalam menghormati HAM (Hak Asasi Manusia) dalam rangka ketertiban bermasyarakat, berbangsa, dan juga bernegara. Adapun, setiap warga masyarakat untuk mendapatkan haknya harus tunduk kepada hal-hal yang telah ditentukan oleh UUD ' 45 agar menjamin hak dan kebebasan masyarakat lainnya sehingga tercipatlah keadilan sesuai dengan nilai-nilai keagamaan dan kebangsaan.

Dinamika sosial masyarakat Indonesia yang ada menyebabkan perlunya rasa saling menghargai, menghormati dan toleransi dalam mewujudkan masyarakat plural. Karena konflik-konflik yang dilandasi perbedaan suku, agama, ras dan golongan (SARA) terjadi di antara masyarakat Indonesia di beberapa wilayah NKRI, salah satu penyebabnya yaitu karena kurangnya pemahaman dan pemaknaan mengenai konsep toleransi yang mampu menjunjung tinggi keragaman (Syam dalam Suratman dkk, 2014: 79). Keragaman masyarakat Indonesia yang ada mengharuskan kita akan perlunya menanamkan sikap toleransi, saling menghargai dan memahami untuk mewujudkan masyarakat yang dinamis.

Dengan kata lain, konflik-konflik SARA tersebut bisa dihindari dengan mengimplementasikan sikap toleran di antara masyarakat. Warga masyarakat harus mampu memahami dan menghargai budaya masyarakat lain sehingga terjalin rasa persaudaraan. Memiliki sikap toleran artinya mampu memahami dan menerima keragaman dengan hati terbuka dan menghormati hak pribadi dan social, masyarakat lain yang menjalani kehidupan mereka. Rani dalam (Sulistyorini dkk, 2016) mengatakan bahwa ada beberapa bentuk toleransi terhadap keragaman, yaitu:

a. Mempelajari dan mengormati budaya masyaraat Indonesia yang berbeda;

b. mecari tahu dan menguasai budaya-budaya yang ada di Indonesia; 
c. merasa bangga akan kekayaan dan keragaman budaya Indonesia;

d. memilih dan memilah kebudayaan luar yang pantas dan tidak dengan nilai bangsa Indonesia.

Dari beberapa bentuk toleransi di atas, masyarakat diharapkan mampu menanamkanya dengan baik sehingga akan mampu membingkai diri dari halhal negatif yang akan mengikis persatuan dan kesatuan bangsa Indonesia. Disamping itu, dengan dinamika sosial masyarakat Indonesia yang terus berkembang, pendidikan toleransi pun dibutuhkan dalam porsi yang lebih banyak karena bangsa kita dihadapkan dengan dunia baru yang semakin berubah. Generasi-generasi yang akan datang akan berubah seiring dengan berkembangnya budaya baru yang berasal dari masyarakat itu sendiri, maka pendidikan toleransi dalam jumlah yang lebih besar akan sangat diperlukan untuk membentengi diri dari konflik dan permusuhan. Dengan kata lain, pendidikan toleransi merupakan hal yang paling utama sebagai alat pemersatu bangsa.

Menurut Usman \& Widyanto (2019: 43-47), nilai-nilai toleransi yang harus dilaksanakan oleh masyarakat Indonesia adalah saling menghargai, bersaudara, kebebasan, kerjasama, tolong menolong, tidak diskriminasi dan berbagi.

\section{a. Saling Menghargai}

Toleransi atau tasamuh (hidup berdampingan secara damai) di lingkungan masyarakat Indonesia yang beragam diperlukan kesabaran. Mengingat, setiap individu masyarakat berbeda-beda dan memiliki standar pemikiran beragam. Nilai kesabaran dan sikap saling menghargai diharapkan mampu menyadarkan masyarakat Indonesia bahwa perbedaan pendapat dan keberagaman itu bukanlah suatu hal yang bisa merusak persatuan dan kesatuan, melainkan menjadi sesuatu yang indah yang terwujud dalam keharmonisan dan kerukunan dalam bermasyarkat. Sikap sabar dan saling menghargai dapat diwujudkan dengan cara tidak menjelek-jelekkan ataupun menghina perbedaan suku, agama, ras dan golongan masyarakat lainnya, melainkan merasa bangga karena memiliki keberagaman yang indah. Jika sikap sabar dan saling menghargai sudah terbentuk di masyarakat pastinya akan menjadi senjata kuat yang melindungi masyarakat Indonesia dari dinamika sosial yang terjadi.

\section{b. Bersaudara}

Sejak awal mula merdeka, keragaman agama dan budaya merupakan ciri khas bangsa Indonesia. Walaupun berbeda-beda, semua warga masyarakat Indonesia hidup bersaudara dan memiliki hak dan kewajibannya masing-masing. Jiwa nasionalisme sejak zaman perjuangan bangsa telah mendorong masyarakat untuk merasa seperti saudara, sehingga keragaman tidak bisa dijadikan langkah untuk saling menjatuhkan melainkan dijadikan sebagai kekayaan dan pemersatu bangsa. Hal ini sesuai dengan isi Pancasila 
yang berarti meskipun terdiri dari beragam suku, agama, bahasa, ras dan juga budaya tetap bersatu. Perdamaian bangsa Indonesia tidak diukur dari perbedaan suku, agama, bahasa, ras dan juga budaya, melainkan dari persaudaraan yang terjalin erat yang tidak bisa putus oleh apapun.

c. Kebebasan

Kebebasan, salah satunya yaitu beragama di negara kita sangat jelas tertulis dalam Undang-Undang Dasar 1945 Pasal 29 Ayat 2, yaitu mengenai kebebasan setiap masyarakat Indonesia dalam memilih agama dan beribadah menurut agama dan kepercayaannya. Sebagai warga negara yang taat akan hukum, sudah seharusnya saling menghargai kebebasan antar sesama bangsa Indonesia. Sikap intoleransi dalam beragama dapat mengakibatkan konflik perpecahan bangsa. Tidak ada pendapat yang salah melainkan hanya ada perbedaan pendapat. Jika kita bisa menghargai perbedaan dengan sikap rendah hati, maka kesatuan dan persatuan Indonesia akan terwujud.

\section{d. Kerjasama}

Kerjasama merupakan fitrah manusia sebagai mahluk yang tidak bisa hidup sendiri. Kerjasama memiliki arti luas dalam masyarakat, baik dalam hal yang positif maupun hal yang negatif. Jika budaya kerjasama dalam hal poitif lenyap oleh arus globalisasi dan modernisasi maka manusia tidak akan lagi peduli karena tidak ada lagi nilai kebersamaan. Manusia akan sibuk akan kepentingannya sendiri tanpa melihat orang lain yang membutuhkan bantuan. Hal tersebut akan membuat bangsa Indonesia rapuh dan mudah hancur. Indonesia merupakan inspirasi toleransi beragama dan multikulturalisme. Dengan mempertahankan budaya kerjasama antara sesama masyarakat Indonesia maka toleransi akan tumbuh dan berkembang yang menjadikan masyarakat Indonesia harmonis dan beradab.

\section{e. Tolong-menolong}

Sejatinya, manusia adalah mahluk sosial yang senantiasa membutuhkan orang lain dalam setiap aspek kehidupan. Tidak ada manusia yang mampu hidup mandiri tanpa pertolongan orang lain. Bahkan dalam memenuhi kebutuhan sandang pangan papan pun manusia memerlukan bantuan. Karena begitu pentingnya kebutuhan ini, sehingga menuntut setiap individu untuk saling tolong menolong. Sifat naluri manusia untuk bergantung pada orang lain inilah yang memunculkan sikap toleransi. Persaudaraan sesama umat manusia yang beragan harus diiringi dengan sikap saling memahami dan tolong-menolong, tanpa memandang individu yang membutuhkan bantuan itu kaya ataupun miskin. Sehingga jika kita ingin hidup di dalam lingkungan masyarakat dengan aman dan harmonis yang dibutuhkan adalah sikap tolong-menolong. 


\section{f. Tidak Diskriminasi}

Didasarkan warisan nenek moyang bangsa Indonesia, masyarakat dikenal telah memiliki sikap toleran terhadap perbedaan yang ada. Perbedaan-perbedaan yang ada tidak dijadikan suatu permasalahan melainkan sebagai langkah untuk saling mengenal satu sama lain, sehingga hubungan antar sesama masyarakat dapat terbina sangat baik. Perbedaan pemikiran dalam suatu hubungan kemasyarakatan yang beragam merupakan hal yang wajar. Namun, karena pemikiran yang berbeda tersebut menjadikan manusia cenderung suka membeda-bedakan yang disebut dengan istilah diskriminasi. Ketika seseorang diperlakukan tidak adil karena perbedaan suku, agama, ras, dan golongan merupakan dasar dari tindakan diskriminasi. Bagi bangsa Indonesia yang memiliki banyak keragaman tidak akan terlepas dari istilah diskriminasi yang menganggap suku, agama, ras, dan golongannya lebih baik dari yang lain. Namun, dengan memahami bahwa diskriminasi adalah hal yang dapat merugikan bangsa bahkan bisa memecah belah persatuan dan kesatuan maka bangsa Indonesia akan tetap kuat.

\section{g. Berbagi}

Berbagi adalah salah satu budaya bangsa Indonesia di samping tolongmenolong dan kebersamaan gotong royong. Namun, seiringnya dengan arus modernisasi dan globalisasi di dalam masyarakat Indonesia menimbulkan pengaruh yang signifikan terhadap budaya bangsa kita, salah satunya budaya saling berbagi. Padahal budaya berbagi mampu menjadi alat pemersatu bangsa. Dengan budaya berbagi kita bisa mewujudkan sikap toleransi dan menjauhkan dari sifat-sifat buruk seperti individualistik dan sikap egoistis yang tidak mau lagi memperdulikan lingkungan sekitar. Untuk mewujudkan masyarakat yang dinamis dan penuh dengan rasa toleransi, masyarakat Indonesia harus menanamkan budaya saling berbagi.

Dari nilai-nilai toleransi di atas, negara Indonesia akan mampu menghadapi dinamika sosial masyarakat yang terus menerus berkembang. Dalam konteks ini, bangsa Indonesia yang menghargai derajat, harkat dan martabat manusia yang lain, memahami perbedaan adalah pencapaian tertinggi dalam pendidikan karena telah mencetak manusia yang toleran dan beradab. Maka istilah bahwa pendidikan adalah simbol peradaban, menjadi sebuah realitas yang patut dibenarkan. Seperti menurut Halim dalam (Ghazali \& Busro, 2017), peradaban suatu bangsa dan negara dikatakan baik atau buruk dapat dilihat dari bagaimana pendidikan dijalani oleh bangsa tersebut.

Menurut Casram (2016: 190) ada dua kelompok dalam masyarakat multikultural, yaitu masyarakat beragama educated people yang mudah diajak bertoleransi terhadap agama dan pemeluk agama lain.dan masyarakat beragama ordiniary people yang mudah terhasut emosi dan susah menanamkan toleransi dengan masyarakat yang berbeda keyakinan. Dari penjelasan tersebut bisa dikatakan bahwa masyarakat beragama educated 
people akan lebih menghargai sikap toleransi, sementara sebaliknya masyarakat bergama ordinary people akan lebih sulit dalam bertoleransi salah satunya mengenai keyakinan agamanya.

Ditengah dinamika sosial masyarakat Indonesia yang memiliki keragaman suku, agama, ras, golongan dan kebebasan berekspresi, manusia dapat hidup secara damai, saling menghormati, menghargai dan saling menerima kekurangan dengan cara menumbuhkan sikap toleransi (Tejokusumo, 2014: 38). Berdasarkan pernyataan tersebut, pendidikan toleransi sangat berhubungan dengan dinamika sosial masyarakat Indonesia, dengan dilandasi sikap saling memahami dan menghormati terhadap manusia lainnya tanpa melihat perbedaan status suku, agama, ras dan golongannya maka toleransi akan menjadi pemersatu bangsa Indonesia.

Toleransi yang terjadi dalam kehidupan sosial masyarakat ditandai dengan sikap hormat menghormati dan menghargai dan ditunjukkan dengan kerjasama dan tolong menolong antar sesama masyarakat tanpa memandang perbedaan (Usman \& Widyanto, 2019: 46). Toleransi dalam kehidupan seharihari masyarakat Indonesia akan dapat mewujudkan kehidupan yang indah, rukun, tenang, dan penuh keharmonisan. Jika di dalam sebuah masyarakat tidak menanamkan sikap toleransi dengan maksimal maka perselisihan seperti halnya yang berhubungan dengan suku, agama, ras, dan golongan akan rentan terjadi.

Wujud pendidikan toleransi dalam dinamika masyarakat Indonesia bukanlah sikap primordialisme (sikap yang selalu membanggakan apa yang dimilikinya), bukan juga sikap Etnosentrisme (mengukur sesuatu atau budayanya dengan apa yang dimiliki) melainkan adalah sikap saling mengerti dan memahami perbedaan satu sama lain. Yang membuat negara Indonesia harmonis, aman dan tentram adalah masyarakat Indonesia itu sendiri. Oleh karena itu, jika masyarakat Indonesia ingin menghadapi dinamika sosial dengan baik maka harus memiliki nilai sikap toleransi yang tinggi.

Nilai-nilai toleransi yang harus ditanamkan oleh masyarakat Indonesia dalam kehidupan sehari-hari adalah saling menghargai, bersaudara, kebebasan, kerjasama, tolong menolong, tidak diskriminasi dan berbagi. Jadi dapat kita simpulkan, bahwa dalam dinamika sosial masyarakat Indonesia di perlukan sikap toleransi yang berasal dari nurani dan tercermin dalam kehidupan sehari-hari dalam mewujudkan kerukunan dan kebersamaan sehingga terwujudlah Bhineka Tunggal Ika yang sesungguhnya.

\section{Simpulan}

Dari uraian di atas bisa ditarik kesimpulan bahwa pendidikan toleransi sangat berpengaruh dalam dinamika sosial masyarakat Indonesia, terlebih masyarakat Indonesia yang terdiri dari berbagai macam suku, ras, budaya, agama, golongan dan lain-lain. Dinamika sosial masyarakat Indonesia yang ada menyebabkan perlunya rasa saling menghargai, menghormati dan 
toleransi dalam mewujudkan masyarakat plural. Konflik-konflik yang dilandasi perbedaan suku, agama, ras dan golongan (SARA) terjadi di antara masyarakat Indonesia di beberapa wilayah NKRI, salah satu penyebabnya yaitu karena kurangnya pemahaman dan pemaknaan mengenai konsep toleransi yang mampu menjunjung tinggi keragaman. Ketika masyarakat Indonesia senantiasa menanamkan nilai-nilai toleransi didalam kehidupannya, maka akan menghadirkan persatuan dan kesatuan bangsa. Nilai-nilai toleransi yang harus ditanamkan oleh masyarakat Indonesia dalam kehidupan seharihari antara lain: saling menghargai, bersaudara, kebebasan, kerjasama, tolong menolong, tidak diskriminasi dan budaya berbagi.

Pendidikan toleransi tidak cukup hanya dengan dipelajari saja, penting bagi warga masyarakat untuk mampu menerapkan dan menanamkannya dalam kehidupan sehari-hari. Karena kerukunan dan keharmonisan tidak akan timbul dengan alami begitu saja, namun harus diperjuangkan dan dipertahankan. Dengan demikian salah satu cara memperjuangkannya yaitu dengan pendidikan toleransi, karena toleransi mampu menjadi alat pemersatu bangsa khususnya dalam dinamika sosial masyarakat Idonesia.

\section{Daftar Pustaka}

Baharuddin. (2015). Bentuk-bentuk perubahan sosial dan kebudayaan. 9(2), 180-205.

Casram. (2016). Membangun sikap toleransi beragama dalam masyarakat plural. Wawasan: Jurnal ilmiah agama dan sosial budaya, 1(2), 187-198.

Digdoyo, Eko. (2018). Kajian isu toleransi beragama, budaya, dan tanggungjawab sosial media. Jurnal Pancasila dan Kewarganegaraan Universitas Muhammadiyah Ponorogo, 3(1), 42 - 59.

Ghazali, AM., dan Busro. (2017). Pendidikan Islam dalam Dinamika Kehidupan Beragama di indonesia. Intizar, 23(1), 93-112.

Hamidah, Siti. (2015). Toleransi perguruan pencak silat (pagar nusa, kera sakti dan psht). Skripsi. Universitas Negeri Yogyakarta.

Lumintang, Juliana. (2015). Pengaruh perubahan sosial terhadap kemajuan pembangunan masyarakat di desa tara-tara. E journal "acta diurna", 4(2). Marnelly, TM. (2017). Dinamika sosial budaya masyarakat melayu pesisir. Jurnal Antropologi: Isu-Isu Sosial Budaya, 19(2), 149-154.

Mawarti, Sri. (2017). Nilai-nilai pendidikan toleransi dalam pembelajaran agama islam, (70-90).

Muawanah. (2018). Pentingnya pendidikan untuk tanamkan toleransi di masyarakat. Jurnal vijjacariya, 5(1), 57-70.

Qadir, Zuly. (2016). Kaum muda, intoleransi dan radikalisme agama. Jurnal studi pemuda, 5(1), 429-445. 
Randa, IRA. 2019. Sikap toleransi mahasiswa lintas etnis dan agama di asrama bujang malaka kabupaten kubu raya. Dayah: Journal of Islamic Education, 2(1), 36-52.

Rasimin. 2016. Toleransi dan kerukunan umat beragama di masyarakat randuacir. INJECT (Interdisciplinary Journal of Communication), (99-118).

Santosa, Bend Abidin. (2017) Peran media masa dalam mencegah konflik. Jurnal Aspikom, 3(2), 199-214.

Sulistyorini, dkk. (2016). Analisis pola interaksi sosial dalam bentuk toleransi antara masyarakat transmigrasi dan masyarakat asli. 5(12).

Suratman, dkk. (2014). Ilmu Sosial dan Budaya Dasar Edisi Revisi. Malang: Intimedia.

Tajuddin, Muhammad Saleh., dkk. (2016). Berbagai kasus konflik di indonesia: dari isu non pribumi, isu agama, hingga isu kesukuan. Sulesna, 10(1), 6372.

Tejokusumo, Bambang. (2014). Dinamika masyarakat sebagai sumber belajar ilmu pengetahuan sosial. Goedukasi. 3(1), (38-43).

Usman, M., dan Widyanto, Anton. (2019). Internalisasi nilai-nilai toleransi dalam pembelajaran pendidikan agama islam di sma negeri 1 lhokseumawe, aceh, indonesia. DAYAH: Journal of Islamic Education, 2(1), 36-52. 